Spring 2010

\title{
The Terror of their Enemies: Reflections on a Trope in Eighteenth- Century Historiography
}

Ronald Schechter

College of William and Mary, rbsche@wm.edu

Follow this and additional works at: https://scholarworks.wm.edu/aspubs

Part of the European History Commons

\section{Recommended Citation}

Schechter, Ronald, The Terror of their Enemies: Reflections on a Trope in Eighteenth-Century Historiography (2010). Historical Reflections/Réflexions historiques, 36(1), 53-75.

https://scholarworks.wm.edu/aspubs/784 accepted for inclusion in Arts \& Sciences Articles by an authorized administrator of W\&M ScholarWorks. For more information, please contact scholarworks@wm.edu. 


\title{
The Terror of their Enemies: Reflections on a Trope in Eighteenth-Century Historiography
}

\author{
Questions, Methods and Definitions
}

On August 26, 1789 the French National Assembly issued the Declaration of the Rights of Man and Citizen, a founding document in the history of human rights. In September 1793 the legislative body known as the Convention inaugurated the infamous Reign of Terror, and in the next ten months more than 16,000 people died on the guillotine. ${ }^{1}$ How was this possible? Why did the French Revolution give birth to the Terror? How could a movement designed to liberate humanity descend into tyranny?

For more than 200 years historians have tried to answer these questions. Some have focused on the circumstances of war and counter-revolution, arguing that the Revolution faced real enemies and unfortunately but inevitably produced innocent victims. Others have seen the Terror as an innate feature of the Revolution, present from the beginning in the Manichean distinctions between virtuous patriots and monstrous aristocrats. Still others have sought the origins of the Terror in the ideas of the Enlightenment, especially the republicanism of Rousseau and like-minded philosophes. ${ }^{2}$

One obvious approach to the subject has been surprisingly overlooked: the history of the concept of terror. After all, "terror” was not a term invented by counter-revolutionaries to discredit their enemies. The revolutionaries themselves proudly invoked the word when describing their preferred form of

\footnotetext{
${ }^{1}$ Donald Greer, The Incidence of the Terror in the French Revolution: A Statistical Interpretation (Cambridge, MA: Harvard University Press, 1935), is still the most reliable study of the number of victims of the Terror, though it is important to note that Greer's figure includes only those put to death by order of revolutionary tribunals. It does not count the much higher number of civil war dead.

2 The historiography of the French Revolution is voluminous, and the question of the Terror alone has produced an enormous amount of scholarship. I attempted to synthesize some of this work in my French Revolution: The Essential Readings (Oxford: Blackwell, 2001), esp. 1-30. Among the recent books dealing with the Terror are: Patrice Gueniffey, La politique de la Terreur: essai sur la violence révolutionnaire, 1789-1794 (Paris: Fayard, 2000); Arno Mayer, The Furies: Violence and Terror in the French and Russian Revolutions (Princeton: Princeton University Press, 2000); Sophie Wahnich, La liberté ou la mort: essai sur la terreur et le terrorisme (Paris: La Fabrique, 2003); David Andress, The Terror: The Merciless War for Freedom in Revolutionary France (New York : Farrar, Straus, and Giroux, 2006); and Jean-Clément Martin, Violence et Révolution: Essai sur la naissance d'un mythe national (Paris: Éditions du Seuil, 2006).
} 
government, and they repeatedly urged their compatriots to place terror “à l'ordre du jour" ("on the agenda”). ${ }^{3}$ Terror was a rallying cry. Revolutionaries deployed it to swell their ranks, encourage likeminded citizens and intimidate their enemies. They used it to legitimize their calls for violence against foreign and domestic foes. Apparently the word was effective, at least until the fall of Robespierre in July 1794. Though other factors were doubtless significant in the creation of the Terror, the name by which it went played no small role in its emergence. But what did the term mean? What is its intellectual history? I am cognizant of the possible pitfalls of tracing the history of a concept over the longue durée. Quentin Skinner has memorably exposed the risks of reifying utterances into timeless ideas that presumably influence thinkers in later generations. He and other exponents of the "linguistic turn" in the social sciences and humanities have tended to focus on linguistic practices or the workings of "discourse” in their analysis of texts. ${ }^{4}$ I am sympathetic to this approach and have profited from discourse analysis in my past work. Yet I have also come to believe that “ideas” and “concepts” are no more problematic as categories of analysis than "society," or "culture," or discourse itself. All categories of analysis involve a degree of simplification or abstraction. Reification is simply the other person's abstraction. One promising approach to the intellectual history of terror, it seems to me, is a Begriffsgeschichte or conceptual history. This method of analysis, developed by Reinhart Koselleck, focuses on the Begriff, a term that connotes both the idea and the word that signifies it. Begriffsgeschichte is therefore compatible with linguistic analysis in general and historical philology in particular. Moreover, whereas traditional intellectual history tended to focus on canonical texts, Begriffsgeschichte uses a broader array of sources

\footnotetext{
${ }^{3}$ Jean-Clément Martin has questioned whether the National Convention officially declared terror to be the “order of the day,” as historians have long presumed, on September 5, 1793. Violence et Révolution: Essai sur la naissance d'un mythe national (Paris: Éditions du Seuil, 2006), 186-93. Yet contemporary newspapers such as the Moniteur cited the expression in more than 20 speeches and letters to the legislature (the Convention), the Parisian municipality (the Commune), and the Jacobin clubs from September 1793 through July 1794.

${ }^{4}$ See esp. Keith Michael Baker, “On the Problem of the Ideological Origins of the French Revolution," in Inventing the French Revolution: Essays on French Political Culture in the Eighteenth Century (Cambridge and New York: Cambridge University Press, 1990), 12-27; and Quentin Skinner, "Meaning and Understanding in the History of Ideas,” History and Theory 8 (1969): 3-53. Baker and Skinner criticized the “unit idea” approach of Arthur O. Lovejoy as exemplified in his Great Chain of Being: A Study of the History of an Idea (Cambridge: Harvard University Press, 1936). For a more sympathetic reading of Lovejoy see Anthony Grafton, "The History of Ideas: Precept and Practice, 1950-2000 and Beyond,” Journal of the History of Ideas (January 2006): esp. 6-9.
} 
to uncover patterns of usage in a variety of contexts. I loosely follow Koselleck's example by examining the concept of terror with close attention to its context but without denying its diachronicity. ${ }^{5}$

In a larger project (still in preparation) devoted to the Begriffsgeschichte of terror I have examined a wide range of sources including theological commentary, political and legal writing, reflections on aesthetics, and medical texts in Europe from antiquity to the eighteenth century. At the risk of oversimplifying, I have found that for many centuries prior to the French Revolution European attitudes toward terror were mainly positive. The Judeo-Christian notion of a terrible God rightfully threatening and punishing his sinful creatures established a firm connection between terror, sovereignty and justice. Earthly rulers attempted to channel this divine authority into their own, coveting the appellation "the terror of their enemies," and insofar as nations assumed the mantle of sovereignty in eighteenth-century Europe, their advocates styled them the terror of other nations. Where "the law" assumed the role of sovereign, it too was obligated to be terrible, and debates over the proper form of punishment typically hinged on the question of which one was most terrible. Aesthetics also played its part in valorizing terror. Dramatic theory from Aristotle through the eighteenth-century made terror one of the salutary emotions (along with pity) ideally evoked in tragedy; and in Edmund Burke’s highly influential theory, adapted from the Greek writer Longinus, terror was a prerequisite of the sublime in painting and other art forms. Even medical science from Galen to the writings of eighteenth-century physicians presented terror as frequently salutary and purgative, a notion with important metaphorical implications for the idea of purging the body politic. When the revolutionaries invoked terror to justify their political program, then, they were taking advantage of the positive connotations the term held with their contemporaries.

In what follows I would like to focus on one genre that furthered the positive valuation of terror, namely historiography. By “historiography” I mean both works devoted primarily to recounting history

\footnotetext{
${ }^{5}$ Melvin Richter and Michaela W. Richter, “Introduction: Translation of Reinhart Koselleck’s 'Krise,' in Geschichtliche Grundbegriffe,” Journal of the History of Ideas 67.2 (2006): 343-356. See also Melvin Richter, "Begriffsgeschichte and the History of Ideas," Journal of the History of Ideas 48 (1987): 247-63; and "Pocock, Skinner, and the Geschichtliche Grundbegriffe,” History and Theory 19 (1990): 38-70.
} 
and texts that more sporadically or casually evoke past ages and events. Specifically, I shall concentrate on statements in which rulers or nations struck terror into their neighbors and/or enemies, or in which a person, a group, or their "name” was the terror of others. This focus has the advantage of revealing the special meaning of terror in the lexicon of fear. In addition to being a "passion," terror could equally be the cause of that passion. Thus, for example, a king could be the terror of his enemies, but not the fear or anxiety of his enemies.

A few definitions of terreur in the century preceding the Revolution can provide a skeletal sense of how the word could denote an emotion or its cause. They also suggest the largely positive connotations associated with the term. In 1690, Antoine Furetière, author of the Dictionnaire universel, defined "terreur" as follows:

Great fright (effroy), passion of the soul caused by the presence of a frightful (affreux), horrible (épouvantable) object. The great Conquerors gained Provinces by the simple terror of their name, of their arms. Aristotle said that Tragedy had to cause terror, or compassion. The bravest people are sometimes subject to panic terrors, or ill-founded horrors (épouvantes). The cruelty of executions was not capable of putting terror in the Martyrs. ${ }^{6}$

The Académie Française, the state-supported institution that had expelled Furetière for pre-empting it in the production of a French dictionary, gave this definition of "terreur" in its 1694 lexicon:

Horror (Espouvante), great fear (crainte), violent agitation of the soul caused by the image of a present ill or a coming danger (d'un peril prochin). Cast terror among ones enemies; spread terror wherever one passes. Fill with terror. He carried terror everywhere. It is said of a great Prince, or of a Conqueror, that he fills everyone with the terror of his name, to say that his name inspires terror everywhere. And panic Terror is what one calls a terror without a subject and without foundation. ${ }^{7}$

In both dictionaries, terror appears first as an emotion, an extreme form of fear, but each lexicon moves immediately to terror as the attribute of a conqueror, i.e. as the ability to inspire sudden and/or extreme

${ }^{6}$ Antoine Furetière, Dictionnaire universel (The Hague, 1690), s.v. “Terreur.” Emphasis in the original. Dominick LaCapra has cautioned against taking Furetière's dictionary as "canonical." For me it is simply one source among many, and a convenient place to begin. "Chartier, Darnton, and the Great Symbol Massacre," in The Journal of Modern History 60 (March 1988): 101.

${ }^{7}$ Le dictionnaire de l'Académie françoise (Paris, 1694), s.v. “Terreur.” Emphasis in the original. 
fear in others. The academy lingers over this version of concept, providing several examples; Furetière is more concise, but he significantly uses the adjective "great" (grands) to describe the "Conquerors" who acquired land through the terror they inspired in their neighbors. The fourth edition of the Academy's dictionary, published in 1762, added new examples testifying to word's meaning as an attribute of rulership: "When speaking of a great Captain, it is said that He is the terror of his enemies. And of a severe Judge, that he is the terror of scoundrels." ${ }^{8}$ Here terror is a metonym, a figure drawing attention to the close association between the emotion and the agent who provokes it. Yet lexicographic citations must only serve as a point of departure for a broader examination of the linguistic evidence.

\section{Terrible Rulers of Antiquity and the Middle Ages}

Historiographical writings of the eighteenth century corroborate the notion that terror (in the sense of terribleness) was a positive attribute of rulers and nations. Abbé Mably, the political theorist whose republican ideas provided what Keith Michael Baker has called a "script” for the French Revolution, ${ }^{9}$ nevertheless lauded a monarch, Philip II of Macedonia, as a model of kingship, writing, “What prudence, what courage in every aspect of this prince’s conduct! ... What knowledge of the human heart! What skill in moving and profiting from the passions! Any prince who has the same genius and acts according to the same principles will certainly have the same success; he will be the terror of his neighbors: he will vanquish his enemies; he will make conquests.” ${ }^{10}$ Commenting on Philip’s more famous son, Alexander the great, Mably wrote admiringly of the "terror of the name of Alexander,"

${ }^{8}$ Dictionnaire de l'Académie françoise (Paris, 1762), s.v. “Terreur.” Emphasis in the original.

${ }^{9}$ Keith Michael Baker, "A Script for a French Revolution: The Political Consciousness of the abbé Mably," in Eighteenth-Century Studies 14 (Spring, 1981): 235-63. Cf. Johnson Kent Wright, A Classical Republican in Eighteenth-Century France: The Political Thought of Mably (Stanford: Stanford University Press, 1997).

${ }^{10}$ Abbé Mably, “Observations sur l'histoire de la Grèce” (1766), in Euvres complètes de l'abbé de Mably (London, 1789-90), vol. 4, 147-8. 
which together with the "thousand heroic qualities" that induced his men to admire him contributed to the conqueror's successes. ${ }^{11}$

The Romans similarly received high praise for their terrible qualities. Most of the commendation went to the citizens themselves, especially during the Republic, as will be seen later. But emperors also earned posthumous respect for their terror. Antoine Jacques Roustan wrote of Probus (232-82), “the terror of his name sufficed to cause [the invading Sarmatians and Goths] to flee.” ${ }^{12}$ The Sieur de Chevigny commended Julian the Apostate (331-363), who had revoked Constantine's endorsement of Christianity and defeated invading barbarians. He wrote in 1706, “Through his wisdom, his constancy, his economy, his conduct, his valor, and a continual succession of heroic actions, [Julian] repulsed the Barbarians, and the terror of his name contained them for as long as he lived.”13 Montesquieu had the identical opinion of the Apostate and accordingly plagiarized Chevigny’s assessment in $1734 .{ }^{14}$ By contrast, emperors who were not terrible were susceptible to historiographical scorn. Hence Edward Gibbon's assessment of Emperor Nerva; he had a "mild disposition” that was "respected by the good; but the degenerate Romans required a more vigorous character, whose justice should strike terror into the guilty. ${ }^{15}$

${ }^{11}$ Abbé de Mably, Observations sur les Grecs (Geneva, 1749), 204-5. Mably did not believe that terror alone was sufficient for producing lasting political institutions, however.

${ }^{12}$ [Antoine Jacques] Roustan, Abrégé de l'histoire moienne (London, 1784), vol. 1, 289.

${ }^{13}$ Sieur de Chevigny, La science des personnes de cour, d'epée et de robe rev., corr. \& considérablement augm. par Pierre Massuet (1706; reprint: Amsterdam, [1752]), vol. 3, 618. On Chevigny see Jeff Loveland, "Unifying Knowledge and Dividing Disciplines: The Development of Treatises in the Encyclopaedia Britannica," Book History 9 (2006): 69.

${ }^{14}$ Charles de Secondat, baron de Montesquieu, Considérations sur les causes de la grandeur des Romains et de leur décadence (Amsterdam, [1734]), 193. Montesquieu wrote: "Ce Prince par sa sagesse, sa constance, son oeconomie, sa conduite, sa valeur, \& une suite continuelle d'actions héroïques rechassa les Barbares, \& la terreur de son nom les contint tant qu'il vécut.” Cf. Chevigny: "Par sa sagesse, sa constance, son économie, sa conduite, sa valeur, \& une suite continuelle d'actions, hérö̈ques, [sic] il rechassa les Barbares, \& la terreur de son nom les contint tant qu'il vêcut." Cf. the contemporary English translation of Montesquieu: "This Prince by his Wisdom, and Perseverance, join'd with Oeconomy, Conduct and Valour, and prospered by a noble Series of heroic Actions, chased the Barbarians out of their new Settlements, and his Name became a Terror as long as he lived.” Montesquieu, Reflections on the Causes of the Grandeur and Declension of the Romans. By the author of the Persian letters. Translated from the French (Dublin, 1734), 136.

${ }^{15}$ Edward Gibbon. The History of the Decline and Fall of the Roman Empire (1776; reprint, London, 1789), vol. 1, 91. 
Though Enlightenment-era historians often disparaged the Middle Ages as a period of superstition and intolerance, they approved of some medieval rulers. ${ }^{16}$ Again, reputation for terror played a role in their ranking. Simon Nicolas Henri Linguet, best known for the exposé he wrote about the conditions in the Bastille - which he described in terms of terror - also wrote a "General History of Europe since 476.” In that book he painted a laudatory picture of the Viking chief Rollo (860-932), a "Prince worthy of founding a state,” who "after having spread terror in all the maritime provinces of Europe, attacked France, took Rouen, fortified himself there, extended his conquests and became so fearsome (redoutable), that Charles the Simple offered him his daughter Gisèle in marriage, with [the province of] Neustria.”17 Henri de Boulainvilliers, a historian who defended the privileges of the nobility against the encroaching power of absolutism, idealized Charlemagne as a ruler who reigned in consultation with the aristocracy. Writing in the 1720s, at a time when nobles hoped the young Louis XV would depart from the absolutism of his predecessor, Boulainvilliers portrayed the combined power of king and nobility as terrifying to neighboring countries. In particular, "It was the Spectacle that he gave every year, not only to Europe subject to his Arms, but to the most distant Nations, whose Kings came from the edges of the Earth to admire it, at least through their ambassadors.” Boulainvillers added, "It was in this way that they brought back an idea of terror and of veneration with which they filled the Universe, and which today is preserved in the Orient." ${ }^{18}$ Thus the principle of terror, so often ascribed by eighteenth-century observers to “oriental” despotism, was a positive idea, linked to veneration and originating in the spectacle of Charlemagne amidst his noble vassals.

\footnotetext{
${ }^{16}$ Henry Vyverberg notes that the Enlightenment view of the Middle Ages was not entirely negative. Human Nature, Cultural Diversity, and the French Enlightenment (New York: Oxford University Press, 1989), 17493.

${ }^{17}$ Simon Nicolas Henri Linguet, Esprit de l'histoire générale de l'Europe. Depuis l'an 476, jusqu'à la paix de Westphalie (London, 1783), 104. For Linguet's description of the “terror” of the Bastille see Mémoires sur la Bastille, et sur la détention de M. Linguet, écrits par lui-même (London [i.e. Berne], 1783), 44.

${ }^{18}$ Henri de Boulainvilliers, comte de Saint-Saire, Etat de la France, dans lequel on voit tout ce qui regarde le gouvernement ecclésiastique, le militaire, la justice, les finances, le commerce, les manufactures, le nombre des habitans, \& en general [sic] tout ce qui peut faire connoître à fond cette Monarchie : extrait des mémoires dressez par les Intendans du Royaume, par ordre du Roi, Louis XIV. à la sollicitation de Monseigneur duc de Bourgogne, Père [sic] de Louis XV, à présent règnant [sic]. Avec des mémoires historiques sur l'ancien Gouvernement de cette Monarchie jusqu’à Huges Capet (London, 1727-8), vol. 3, 13.
} 
Other medieval "terrors” received high marks from eighteenth-century historians. The Neapolitan historian Pietro Giannone, whom J.G.A. Pocock has called a "proto-Enlightened historian” and whose advocacy of religious freedom earned him more than a decade in prison at the hands of the Inquisition, insisted that Roger II of Sicily (1095-1154) was not the usurper Saint Bernard had made him out to be. Rather he was a "great and glorious Prince, whose magnanimous exploits raised him to be one of the most powerful and greatest men in the world, who struck no less terror into the emperors of the West as into those of the East.” ${ }^{19}$ Clearly for Giannone terror was one of the attributes that legitimized the Sicilian king. Giannone also approved of Roger’s successor, William II (1154-89), “the honor of the nobility, the confidence of his friends, the terror of his enemies, the life and virtue of the people, the poor and the pilgrims, the salvation and strength of the suffering.”20 The leaders of both sides of the Crusades were terrible, according to historian Isaac de Larrey; Saladin was the "greatest man of war that the Turks ever had” and a leader who "carried terror everywhere he appeared," and Richard the Lionhearted was "so feared (redoute) by the Sarassins that even after his death he remained their terror." 21 Even the relatively pacifistic Fénélon instructed the duc de Bourgogne (the heir to the French throne) to imitate the crusading king Louis IX (Saint Louis), "the delight of the good, and the terror of the wicked.”22

\footnotetext{
${ }^{19}$ Pietro Giannone, Istoria civile del regno di Napoli, ed. Antonio Marongiu (1721; reprint, Milan: Marzorati, 1970), vol. 3, 94-5.

${ }^{20}$ Giannone, Istoria civile, vol. 3, 174.

${ }^{21}$ Isaac de Larrey, Histoire d'Éléonor de Guyenne, duchesse d'Aquitaine; contenant ce qui s'est passé de plus mémorable, sous les regnes de Louis VII, dit le Jeune ... (London [i.e. Paris?], 1788), 277 and 365.

${ }^{22}$ François de Salignac de La Mothe-Fénelon, Euvres spirituelles de Messire François de Salignac de La Mothe-Fénelon, Archévêque-Duc de Cambrai, Prince du S. Empire. Volume Second. Contenant ses Lettres Spirituelles (Antwerp, 1718), 9. Cf. Letters to the Duke of Burgundy, from Mr de Fénelon ... (Glasgow, 1746), 11: "St. Lewis at your years had made himself the delight of the good and the terror of the wicked." On Fénelon's pacifist leanings see David Avrom Bell, The First Total War: Napoleon's Europe and the Birth of Warfare as We Know It (Boston: Houghton Mifflin, 2007), 58-62.
} 


\section{Recent Terrors as Objects of Emulation}

Praising a past monarch as "terrible" could serve as a subtle (or not so subtle) critique of a contemporary ruler, or at least an expression of high expectations for the current reign. ${ }^{23}$ Thus Dreux du Radier, a historian who ended up in exile for making seditious remarks about Louis XV, praised Charles VIII (reigned 1470-98) as "this great Prince, who had been the terror of Italy and the admiration of all of Europe at the age of seventeen.”24 Even more revered was Henri IV, whose reputation for terror played an important part in his posthumous image. On the occasion of the birth of the Duke of Burgundy in 1682, a poet (an anonymous "lady”) held out high hopes for the Bourbon scion, whom she expected to show himself "Worthy of the scepter of the French:/ Numerous Louis, a Charlemagne,/ A Henry terror of Spain.”25 This catalogue of worthy predecessors was not merely an example of requisite flattery; it reflected contemporary standards of kingship. A more obvious use of Henri IV to castigate the current occupant of the throne appears in an anonymous libelle in which a fictitious spy overhears the royal mistress Madame de Pompadour comparing Louis XV unfavorably with his ancestors. Beginning with Henri IV, she says, "Like you, he loved women to excess, he was their dupe, as you are, but he compensated for his faults with so many brilliant qualities that they [his faults] were all forgotten.” She adds, "He was frank, humane, affable, popular, he was the terror of his enemies and the father of his people.”26 The figure of Madame de Pompadour is not sympathetic in this depiction, but her assessment

\footnotetext{
${ }^{23}$ See Colin Jones's remarks on the veneration of Henri IV as a veiled critique of the later Bourbons, "Pulling Teeth in Eighteenth-Century Paris,” Past and Present 116 (February 2000): 110.

${ }^{24}$ M. (Jean-François) Dreux du Radier, Tablettes historiques et anecdotes des rois de France, depuis Pharamond jusqu'à Louis xiv Second edition (Londres, 1766), Vol. 2, 14. On Dreux's exile see Robert Darnton, “Policing Writers in Paris Circa 1750," Representations 5 (Winter 1984), 25. The chevalier d'Eon wrote of Charles VIII's progress in the Italian wars, "Terror marched before him.” Charles Geneviève Louis Auguste André Timothée d'Eon de Beaumont, Memoires pour servir a l'histoire générale des finances (London [i.e. Paris], 1758), 124. On the chevalier see Gary Kates, Monsieur d'Eon Is a Woman: A Tale of Political Intrigue and Sexual Masquerade (New York: BasicBooks, 1995).

${ }^{25}$ Dominique Bouhours, The Art of Criticism: or, the Method of Making a Right Judgment upon Subjects of Wit and Learning. Translated from the best edition of the French, of the Famous Father Bouhours, by a Person of Quality (London, 1705), 77. The poem appears in French in The Art of Criticism. I have translated the quotation.

${ }^{26}$ Anecdotes échappées à l'Observateur anglois et aux Mémoires secrets, en forme de correspondance; pour servir de suite à ces deux ouvrages (Londres [i.e. Paris??], 1788), 112. In 1750 the lawyer and publicist of
} 
of Henri IV was expected to be shared by readers. Thus Louis XV paled because, among other things, he was not the terror of his enemies.

Indeed, one of the attributes that made Louis XIV "great” was his ability to terrify France’s enemies. When Voltaire wrote his Siècle de Louis XIV (1751), he celebrated the most victorious years of the reign (in the 1670s) as a time when the king was "the terror of Europe” and France was a "happy nation.”27 At this point in his life Voltaire was living at the court of Frederick the Great, the "Philosopher King” whom he unequivocally viewed as superior to Louis XV. Indeed, in several other places Voltaire described Frederick favorably as a "terror."28 The past terror of the Sun King was more overtly deployed in 1758 when a merchant guild opposed a reduction in the production of certain products during the Seven Years' War. The guild's spokesmen pointedly argued to Louis XV that “there were no fewer manufactures ... when your August Predecessor, Sire, supported those Corps of formidable Troops that made him the terror of his enemies.”29

In fact Louis XIV's reputation for terror began during his reign. Madame de Montpensier, who had fought against Louis XIV (or, more precisely, the Regency of his mother) during the Fronde, came back to his side and in 1658 praised him as "the love of his peoples, the veneration of all the Court, and the terror of his enemies.” ${ }^{30}$ In an ode to Louis XIV on the subject of his support of scholarship,

causes célèbres, Gayot de Pitaval, recalled the "horrible assassination that removed from his Kingdom Henry IV, who was its delight, and the terror of his Enemies." Gayot de Pitaval, Causes Célèbres et Interessantes, Avec Les Jugemens Qui Les Ont Decidées; Recueillies Par Mr. Gayot De Pitaval, Avocat Au Parlement de Paris (The Hague, 1750), vol. 14, 20. On the place of causes célèbres in the political culture of Old Regime France see Sarah Maza, Private Lives and Public Affairs : the Causes Célèbres of Prerevolutionary France (Berkeley and Los Angeles : University of California Press, 1993).

${ }^{27}$ Voltaire, Le Siècle de Louis XIV, in Louis Moland, ed., Euvres complètes, vol. 19, 440.

${ }^{28}$ As early as 1742, in the midst of the War of the Austrian Succession (in which Prussia and France were allies) he had fawned over the young monarch in the following terms: "I worry about humanity, Sire, before I worry about you; yet after having wept with the abbé de Saint-Pierre [who had written a pacifist tract] for the human race, of which you have become the terror, I give myself over to all the joy that your glory gives me." Voltaire to Frederick, 26 May 1742, in Les æuuvres complètes de Voltaire/The Complete Works of Voltaire, ed. Theodore Besterman (Geneva: Institut et Musée Voltaire, 1968), vol. 36, 129. In his subsequent history of the War of the Austrian Succession, Voltaire described Frederick as a "useful" ally for France because he "was the terror of the Austrians.” Voltaire, Histoire de la guerre de mil sept cent quarante \& un. Premiere partie (London, 1756), 274.

${ }^{29}$ Marchands merciers, Au roi ([n.p.], [1758 ?]), 3.

${ }^{30}$ Mademoiselle de Montpensier, "Portrait du Roy, Ecrit à Paris le septiéme Octobre 1658. Par Mademoiselle," in Mémoires de mademoiselle de Montpensier (London [Paris], 1746), vol. 7, 340. 
Antoinette Deshoulières did not omit to laud the monarch for "spreading terror from the Ganges to the ice flows.” ${ }^{31}$ Even during the funeral of the Sun King’s wife in 1682 Bishop Bossuet took the occasion to observe that "French bravery carries terror everywhere with the name of Louis." ${ }^{2}$ More concrete attempts at enshrining Louis as “terrible” include a coin struck to celebrate France’s conquest of Besançon in 1668. It depicts Louis XIV on the obverse and displays the caption "TERROR NOMINIS" (the terror of his name) on the reverse. ${ }^{33}$ (See Figure 1.) Similarly, Under a statue of Louis XIV at the Episcopal Palace an inscription identified him as “Ce Heros, la terreur, l’amour de l'univers” (“This Hero, the terror, the love of the world"), suggesting that it was quite possible to love and fear the king at the same time. ${ }^{34}$

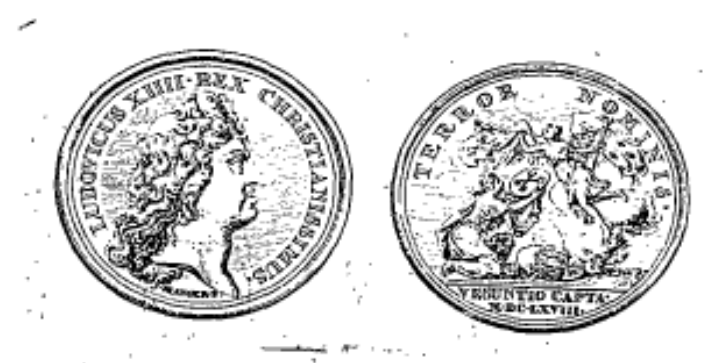

La Tête eft la même que celle de la Médaille précédente: Le Revers repréfente la Ville de Be-
zançon, fous la figure d'une Femme à genoux, qui publie les louanges du Roi ; avec ces mots fur le tour :

TER R O N O M I I S.

${ }^{31}$ Antoinette Deshoulières, "Ode sur le soin que le Roi prend de l'éducation de sa noblesse dans ses Places \& dans Saint-Cyr, laquelle remporta le prix à l'Académie françoise. 168-," in Euvres choisies de Madame et de Mademoiselle Deshoulières (Londres [i.e. Paris ], 1780), Vol. 2, 31. On Deshoulières, who was also a playwright and member of the Academia dei Ricovrati in Padua, see Siep Stuurman, "Literary Feminism in SeventeenthCentury Southern France: The Case of Antoinette de Salvan de Saliez," The Journal of Modern History 71 (March 1999), 18; and English Showalter, Jr., "Writing off the Stage: Women Authors and Eighteenth-Century Theater," Yale French Studies 75 (1988), 96.

32 Jacques Benigne-Bossuet, Bishop of Meaux, Recueil des oraisons funèbres, prononcées par Messire Jacques Benigne-Bossuet, Evêque de Meaux. Nouvelle Édition, Augmentée de l'Elonge Historique de l'Auteur, \& du Catalogue de ses Ouvrages (Paris, 1734), 176. Cf. Bridel Arleville, Le petit rhétoricien françois, ou abrégé de la rhétorique françoise ... avec des exemples tirés des meilleurs orateurs et poëtes modernes (London, 1791), 182.

${ }^{33}$ Gerard van Loon, Histoire metallique des XVII provinces des pays-bas, depuis l'abdication de CharlesQuint, jusqu'à la paix de Bade en MDCCXVI (The Hague, 1732-37), vol. 3, 12. On the importance of commemorative medals in the king's self-representation see Peter Burke, The Fabrication of Louis XIV (New Haven: Yale University Press, 1992), passim.

${ }^{34}$ Dominique Bouhours, The Art of Criticism: or, the Method of Making a Right Judgment upon Subjects of Wit and Learning. Translated from the best edition of the French, of the Famous Father Bouhours, by a Person of Quality (London, 1705), 23. The inscription is quoted in the original French. 
Figure 1. Louis XIV: one of his weapons was simply "the terror of his name.”

The idea that a king must be the terror of his enemies was even enshrined in his coronation oath, which required him to be the "pavor, terror et formido" - the first two words are synonymous with terror, and "formido" roughly means fear or dread - to "foreigners and plotters" (aliisque insidiantibus). ${ }^{35}$ The sixteenth-century jurist and theorist of absolutism, Jean Bodin, buttressed this idea when he included among "the true signs of a great King” that he be "terrible to his enemies, courteous to honest people, fearsome (effroyable) to the wicked, and just towards all." ${ }^{36}$ Such programmatic statements helped to form historical representations of good kings, which in turn solidified expectations of monarchs to be the terror of their enemies.

Historical representations of English rulers similarly deployed the vocabulary of terror. In 1702 John Dunton praised Queen Mary as a monarch who “dismay’d her Enemies by the Terror of her Arms.”37 Queen Elizabeth was similarly characterized as terrible. In her late sixteenth-century war against Philip II, according to a book appearing in 1745 and bearing the innocuous title A Collection of Voyages and Travels, the queen "carried on the war against Spain with so much conduct and success, both in Europe and America, that the English became every where a terror to the Spaniards.”38 This eulogy had particular resonance in 1745, which was not only the year of the second Jacobite Rising (and its suppression) but also a time when "patriots" were calling for war against Spain. Fifteen years later, in

\footnotetext{
${ }^{35}$ Les efforts de la liberté \& du patriotisme contre le despotisme (London, 1772-3), vol. 4, 189n. Cf. Richard A. Jackson, ed., Ordines coronationis Franciae: Texts and Ordines for the Coronation of Frankish and French Kings and Queens in the Middle Ages, vol. 2, 478: "Exaudi, Domine quesumus, preces nostras, et hunc gladium quo famulus tuus $\mathrm{N}$. se accingi desiderat, maiestatis tue dextera benedicere dignare, quatinus deffensio atque protectio possit esse ecclesiarum, viduarum, orphanorum, omniumque Deo servientium contra sevitiam paganorum, aliisque insidiantibus sit pavor, terror et formido."

${ }^{36}$ Jean Bodin, "Les vrayes marques d'vn grand Roy,” book 2 of Les six livres de la repvbliqve de I. Bodin Angeuin (Paris, 1576), 465.

${ }^{37}$ John Dunton, The history of living men: or, characters of the royal family, the ministers of state, and the principal natives of the three kingdoms. Being an essay on a thousand persons that are now living. With a poem upon each life (London, 1702), 28.

${ }^{38}$ A Collection of Voyages and Travels, Consisting of Authentic Writers in our own Tongue (London, 1745), vol. 1, 75.
} 
the midst of the Seven Years War, Joseph Grove repeated almost the quotation from A Collection of Voyages and Travels.” 39

Representations of William III likewise focused on the king's terror. As with Louis XIV, such depictions began during his reign. A medal struck to advertise his power and majesty styled the king “omnis propinqui terror,” or the terror of all his neighbors. ${ }^{40}$ (See Figure 2.) A medal minted in 1691 to celebrate the surrender of Galloway during the Jacobite rebellion features the same ruler and depicts his victory as having been won "by his arms and by the terror of his name (armis, nominisque terror)." 41 (See Figure 3.) These images survived the king's death. A French Protestant in Leiden, Auguste de Gabillon, held a funeral service for William in 1707 in which he called him a "Prince whose name alone was capable of inspiring terror.” Further in his eulogy Gabillon described William and Mary, “The one frightened enemies of his Fatherland; the other inspired terror in the enemies of truth." 42 Seven years later the Huguenot pastor Jean-Armand Dubourdieu called William the “Terreur des Mechans” (Terror of the Wicked). ${ }^{43}$ An anonymous Francophone writer, possibly also a Huguenot émigré, in 1723 remembered William III as "the terror of his enemies and the delight of his subjects." 44

\footnotetext{
39 Joseph Grove, A Second Letter to a Right Honourable Patriot, on the Glorious Victory Obtained over the Brest Fleet 1759 (London, 1760), 17.

${ }^{40}$ Van Loon, Histoire metallique, vol. 3, 395, 397.

${ }^{41}$ Van Loon, Histoire metallique, vol. 4, 56.

42 Auguste de Gabillon, Oraison funebre de très haut, très puissant, très excellent, \& très pieux monarque, Guillaume III. Roi d'Angleterre, ... Prononcée à Leyde ... Seconde édition (London, 1707), 17.

${ }^{43}$ Jean-Armand Dubourdieu, Les vœux des protestants : ou sermon sur le 1 Sam. ch. x ver. 24. Prononcé le dimanche aprés l'entrée du roy.... Second édition (Londres, 1714), 19.

${ }^{44}$ Le génie anglois, ou histoire abrégée des révolutions fréquentes de la Grande-Bretagne; par un esprit desintéressé (Dublin, 1723), 358.
} 

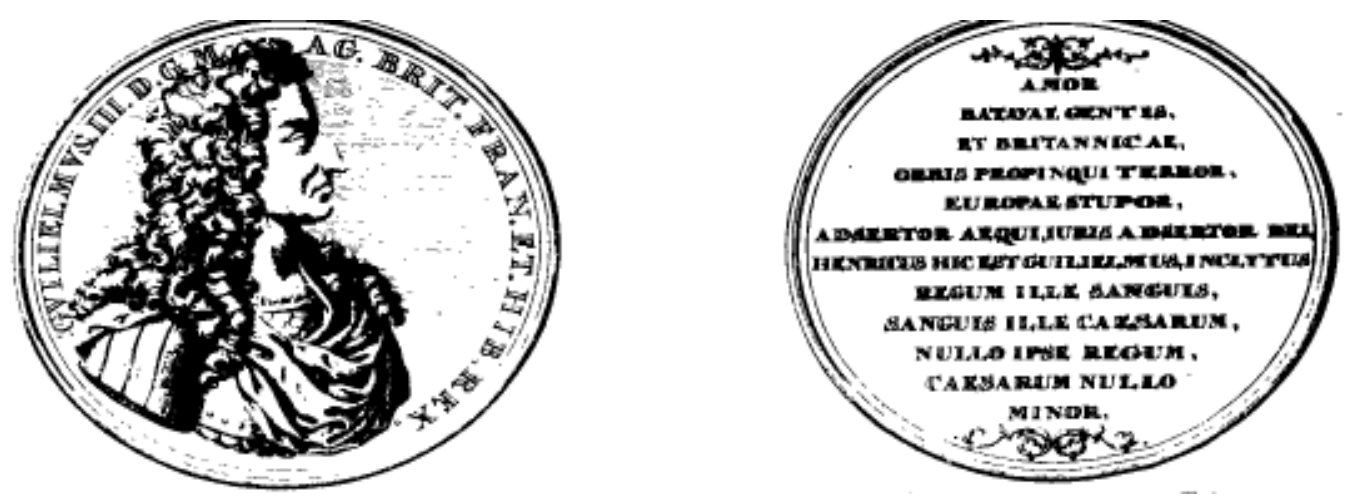

Figure 2. William III as "the terror of all his neighbors.”
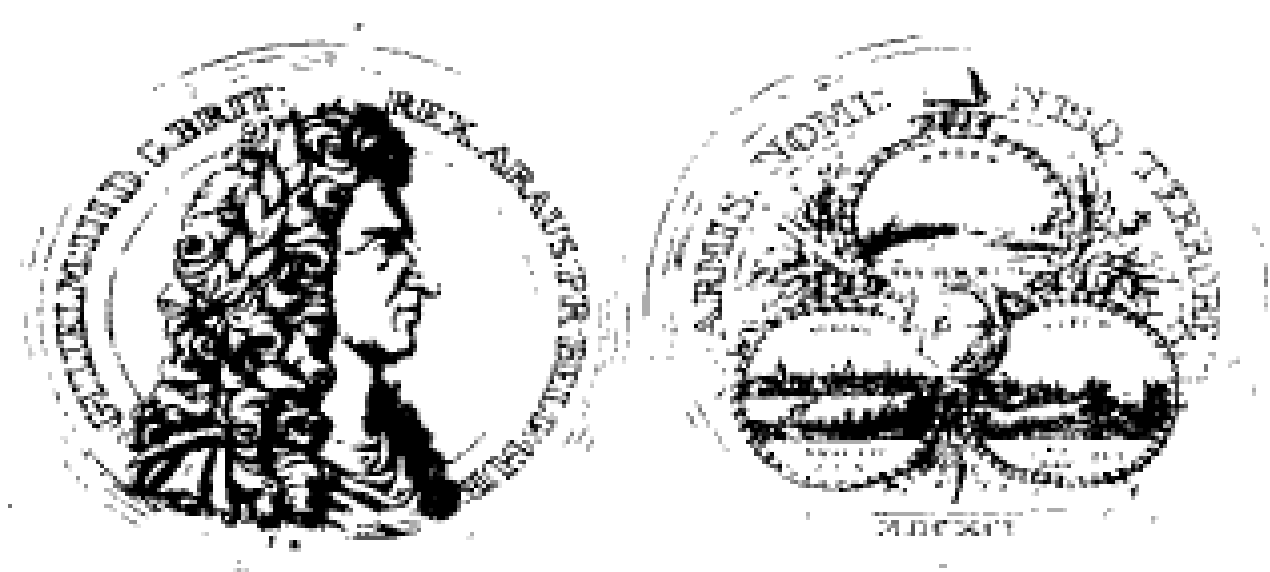

Figure 3. William III subduing Galloway "by his arms and by the terror of his name.”

As the focus of this essay is on historiographical representations, I shall not dwell on how

eighteenth-century writers described their contemporary rulers. It suffices to observe that the habit of

praising French and English monarchs (among rulers of other states) as terrors lasted throughout the

eighteenth century. The French Regent (the Duke d'Orléans), Louis XV and Louis XVI were designated the terror of their enemies or neighbors. ${ }^{45}$ So were all three Georges in Britain. ${ }^{46}$ Historiography

${ }^{45}$ Henri de Boulainvilliers, comte de Saint-Saire, Etat de la France, dans lequel on voit tout ce qui regarde le gouvernement ecclésiastique, le militaire, la justice, les finances, le commerce, les manufactures, le nombre des habitans, \& en general [sic] tout ce qui peut faire connoître à fond cette Monarchie : extrait des mémoires dressez par les Intendans du Royaume, par ordre du Roi, Louis XIV. à la sollicitation de Monseigneur duc de Bourgogne, 
furthered the practice of acclaiming contemporary rulers in these terms insofar as it reminded readers of the venerable attributes of rulership.

Other past terrors, according to eighteenth-century writers, included a series of Swedish kings.

Gustavus Adolphus (1594-1632) earned the respect of historian Walter Harte for "the great terror" he and his army struck in the troops of the Holy Roman Empire. ${ }^{47}$ The comte de Guibert, whom David Bell calls “France’s most influential pre-Revolutionary military reformer,” also admired the Swedish ruler who "with [the comparatively small army of] twenty-five thousand Swedes was the terror of the Empire."48 The Swedish King Charles X similarly received high marks for inspiring terror. Paul Henri Mallet, in his Histoire de Dannemarc remarked admiringly on "his passion, his talent for war, his activity ... the respect

Père [sic] de Louis XV, à présent règnant [sic]. Avec des mémoires historiques sur l'ancien Gouvernement de cette Monarchie jusqu'à Huges Capet (London, 1727-8), vol. 3, 541; [Charles Gabriel], abbé de l'Attaignant, Poesies de M. l'Abbé de L'Attaignant; contenant tout ce qui a paru de cet auteur sous le titre de piéces dérobées.... (London [i.e. Paris?], 1756-57), 166; Comte [Louis-Gabriel] Du Buat, Les maximes du gouvernement monarchique, pour servir de suite aux Éléments de la politique. Par le même auteur (London [i.e. Paris?], 1778), 472; Jan Voorman, Bataven! zie met vreugd in deze beeldtenis, de schradere Lodewyk, de schrik van Groot Brittanje, uw hulp en bondgenoot, wiens oog steeds wakend is, op 't ruig - het slaafsch gevoel der aanhang van Oranje. Wensch u en Frankryks volk geluk met dezen held, die in menschlievenheid zyn hoogste wellust steld (n.p., [1786]).

46 "Truth on both Sides," in Mughouse-diversion. Or, a Collection of Loyal Prologues, and Songs, Spoke and Sung at the Mug-Houses. Most of Which Were Never Yet Printed (London, 1717), 10; Johann Peter von Ludewig, Die, von Sr. Königlichen Majestät, unserm allergnädigstem Könige, auf dero Universität Halle, am 14 iulii 1727 neu angerichtete Profession, in OEconomie, Policey, und Cammer-Sachen wird, nebst Vorstellung einiger Stücke verbesserter Kön. Preussl. Policey, bekannt gemachet von dem zeitigem Prorectore, Joh. Peter von Ludewig.... (Halle, 1727), 3; George Woodward, A Poem to the Glorious Memory of His Sacred Majesty King George I (London, 1727), 4; “The Revolution,” in The London Magazine: or, Gentleman's Monthly Intelligencer (London, [1732-1735]), vol. 3 [June 1734], 323; Chaunter Humphrey, King George for England. A New Ballad, to An Old Tune: Necessary to be Sung by All True and Loyal Englishmen, Upon All Occasions; More Especially at the Present Conjuncture (London, 1745), 5; Edmund Weaver, The British Telescope: Being an Ephemeris of the Colestial Motions. With an Almanack for the Year of our Lord 1744 (London, [1744]), no page number; John Angell, An Essay on Prayer, the Nature, Method, and Importance, of that Duty (London, 1760), 303; Samuel Davies, A Sermon Delivered at Nassau-Hall, January 14. 1761. On the Death of His Late Majesty King George II (Boston, [1761]), no page number; The Songster's Newest Delight: Containing Twenty of the Most Choice and New Songs ([London], [1761?], no page number; Giovan Gualberto Bottarelli, Le speranze della terra, ovvero il tempio del destino, serenata-Eseguita la prima volta sopra il Teatro Reale di Hay-Market, il quattro di Giugno ... (London, 1761), 55, 54; The Merry Midnight Mistake, or Comfortable Conclusion, A New Comedy (Chelmsford, 1765), 25; Consolatory Thoughts on American Independence; Shewing the Great Advantages that will Arise from it to the Manufactures, the Agriculture, and Commercial Interest of Britain and Ireland (Edinburgh, 1782), 47.

${ }^{47}$ Walter Harte, The History of the Life of Gustavus Adolphus, King of Sweden, sirnamed, the Great (London, 1759), vol. 1, 358.

${ }_{48}$ Jacques Antoine Hippolyte, comte de Guibert, Essai général de tactique, précédé d'un discours sur l'état actuel de la politique \& de la science militaire en Europe (London [i.e. Liège], 1773), vol. 2, 38. Bell, First Total War, 79. 
and the terror that he had inspired within and without his states." ${ }^{49}$ Referring to the same king's campaign in Poland in 1655, Mably wrote, "Never had progress been so rapid; everything bent under the initial blows of Charles; terror went before him, his enemies fled, their arms fell into his hands." ${ }^{50}$ As for Charles XI, The Milanese Protestant and historian Gregorio Leti wrote: "His high virtues undeniably cast more brilliance than the jewels in his Crown, his courage equaled that of Caesars and Alexanders, his projects full of generosity made the whole world recognize him for one of the most beautiful souls ever seen and rendered him the terror of all Europe.”51 Voltaire wrote of Charles XII, who fought the forces of the Russian Tsar, Danish king and Polish king in 1700: "King Charles [XII], at the age of sixteen, vanquished all three. He was the terror of the North and was already esteemed a great man at an age when others have not even finished their education.”52 In his Histoire de Charles XII Voltaire referred glowingly eight times to the terror of Swedish king’s arms or name. ${ }^{53}$ Mably followed suit, calling Charles a "hero” and writing of the aftermath of the battle of Nerva (1700): “Terror preceded Charles in Poland; it chased Augustus [king of Poland] and gave the crown to Stanislas,” the Swedish-supported candidate. $^{54}$

Lesser princes could be known as terrors if their military accomplishments were considered significant. Thus Frederick the Great, who aspired to this status himself, described his great-grandfather, the "Great Elector" of Brandenburg, who had won territory at the expense of Sweden in the late seventeenth century. Frederick wrote, "He left Berlin in 1679, put himself at the head of 9000 men” and “crossed the Vistula on 15 January, preceded by the terror of his name, which had become fearful

\footnotetext{
${ }^{49}$ Paul Henri Mallet, Histoire de Dannemarc (Geneva, 1763), vol. 3, 432, cited in William Coxe, Travels into Poland, Russia, Sweden, and Denmark, Interspersed with Historical Relations and Political Inquiries (Dublin, 1784), vol. 3, 104.

${ }^{50}$ Abbé Mably, “Le droit public de l'europe,” in Euvres complètes de l'abbé de Mably (London, 1789-90), vol. 5, 298-99.

${ }^{51}$ Gregorio Leti, Le portrait et la vie secrette de la Reine Christine de Suede. Avec un veritable recit du sejour de la Reine à Rome (London, 1710), 4-5.

${ }^{52}$ Voltaire, Siècle de Louis XIV (1752), in Moland, ed., Euvres complètes, vol. 14 (Paris, 1878), 328. In his Histoire de L'Empire de Russie sous Pierre le Grand (1759) Voltaire wrote of Charles's campaign of 1703, “He spread terror in upper Poland, in Silesia, in Saxony.” Moland, ed., Euvres complètes, vol. 16, 491.

${ }^{53}$ Voltaire, Histoire de Charles XII, roi de Suede (1731; reprint, London, 1756), 11, 79, 80, 83, 138, 146, 264, 306.

${ }^{54}$ Mably, “Droit public,” in Euvres complètes, vol. 6, 172, 175.
} 
(redoutable) to the Swedes.”55 Prince Eugene of Savoy was even more widely heralded in similar terms for his defeat of Ottoman forces at the battle of Zenta in 1697. In 1733 Jean Rousset de Missy, an exponent of the "Radical Enlightenment," ${ }^{56}$ praised the "valiant Prince Eugene" in the highest terms, noting that he "gave borders to the [Ottoman] Crescent, and taught it to fear (craindre) truly the Roman Eagle,” i.e., the Habsburg Empire. Missy added that the Ottoman forces were forced to "deal with this terror in the Divan." ${ }^{57}$ In the 1780s Eugene was still remembered as "the terror of Asia and the greatest Captain of Europe.”58

Just as monarchs held the title of terror to their enemies or neighbors, their commanders in the field and on the sea enjoyed the same distinction in deputized form. (One might argue the reverse, from the commanders' point of view, i.e. that rulers were only terrible insofar as their military leaders were.) Eighteenth-century writers judged commanders past and present in large measure according to their ability to inspire terror. One particularly striking example of the veneration of terror in past commanders comes from a 67-volume work of French history - the Collection universelle (1785-90) - edited by Alexandre-Claude Bellier-Duchesnay. Two volumes deal specifically with the fourteenth-century French soldier Bertrand du Guesclin, "the terror of the English and the Spaniards, and the preserver of the Crown of France.”59 “His name alone,” the reader learns, was “the terror of the English and the Navarrese.”60 Bertrand was a man "who had made himself the terror of all Europe through the memorable expeditions he had launched, and whose name alone was so redoubtable, that it cast fright (frayeur) and fear (crainte)

\footnotetext{
1750), 121.

${ }^{56}$ Jonathan I. Israel, Enlightenment Contested: Philosophy, Modernity, and the Emancipation of Man 16701752 (Oxford: Oxford University Press, 2006), 400-403. On Missy's role in the production of the Spinozist Treatise of the Three Impostors see Margaret C. Jacob, The Enlightenment: A Brief History with Documents (Boston and New York: Bedford/St. Martin’s, 2001), 19.

${ }^{57}$ Jean Rousset de Missy, Les interêts presens des puissances de l'Europe, fondez sur les traitez conclus depuis la paix d'Utrecht inclusivement.... (The Hague, 1733), vol. 1, 136.

${ }^{58}$ Réponse à un article des Annales politiques de Mr. Linguet, no.17, concernant la défaite du Gen. Burgoyne en Amerique (London, 1778), 17.

${ }^{59}$ Collection universelle des mémoires particuliers relatifs à l'histoire de France (Londres [i.e. Paris?], 1785-90), vol. 3, 347.

${ }^{60}$ Collection universelle, vol. 4, 50.
}

${ }^{55}$ Frederick II, King of Prussia, Mémoires pour servir a l'histoire de Brandebourg (Berlin [i.e. London?], 
into the minds of his enemies.”61 In Spain people could not even pronounce his name without trembling. ${ }^{62}$ After one battle that Bertrand won, “The whole countryside was frightful to see, being covered with heads, arms, overturned helmets, all bloodied, and broken swords. This pitiable scene gave such terror to the English that they hardly fought anymore.”63

The English were not absent from the eighteenth-century catalogue of terrible commanders, however. Among seventeenth-century commanders celebrated for their terror was the privateer Sir Henry Morgan, whom one eighteenth-century historian of Jamaica called "the terror of Spain.” ${ }^{64}$ On land General George Monk, who fought for Cromwell during the English Civil War, earned David Hume’s esteem for his destruction of the Scottish town of Dundee in 1651. Making explicit what he meant by “terror,” Hume wrote that the "able general ... put the whole inhabitants to the sword, in order to strike a general terror into the kingdom.” This tactic was effective, according to the philosopher-historian: "Warned by this example, Aberdeen, St. Andrews, Inverness, and other towns and forts, of their own accord, yielded” to Cromwell’s forces.”"65

\section{Terrible Nations}

If terror was an attribute of sovereigns and their military commanders, it also applied to nations. As the concept of the sovereign nation emerged in eighteenth-century political discourse, this new entity adopted many of the features of sovereign kingship. Historical representations therefore included “terrible” nations, either as reminders of past glory or as foreign examples worthy of emulation. The Romans loomed especially large in this array of nations. Highlighting the moral stature of Republican

${ }^{61}$ Collection universelle, vol. 4, 373.

${ }^{62}$ Collection universelle, vol. 4, 121-22.

${ }^{63}$ Collection universelle, vol. 5, 13.

${ }^{64}$ Charles Leslie, A New History of Jamaica, from the Earliest Accounts, to the Taking of Porto Bello by Vice-Admiral Vernon ... (London, 1740), 57, 106; Cf. Histoire de la Jamaïque, traduite de l'anglois. Par M.***, ancien officier de dragons (London [i.e. Paris?], 1751), vol. 1, 221, 281.

${ }^{65}$ David Hume, The History of Great Britain (London, 1757), vol. 2, 36. 
Rome, Mably wrote glowingly of the citizens' “civic virtues, political virtues, love of glory, love of the fatherland, austere and wise discipline," noting that with these virtues "they could inspire terror” in their enemies. ${ }^{66}$ Recalling the republican victories over various barbarians in the first century B.C., he wrote, "Rome did not cease to triumph, because its Legions were always better disciplined and more seasoned that the armies of their enemies; and the advantages that [Rome] had over them inspired a just terror in the provinces that had lost the last sentiment of liberty." ${ }^{67}$ In 1756 (the year in which the Seven Years' War broke out) Abbé Coyer, an economist who encouraged the nobility to become involved in commerce, made the argument for capitalism by referring to the terror the ancient Romans were able to inspire through their navy. He wrote, "Let us never forget that it is commerce that forms the Navy; that we would not have any armed fleets if we had not begun with merchant fleets; and that the Romans conquered in 50 years since they had vessels what they had not conquered in 300. Land armies only carry terror to a single place. The sea unites power with speed, it surrounds the land and forces it to submit.”68 Gibbon, focusing his attention on the Roman armies, suggested that precisely by being "terrible” they prevented unnecessary bloodshed during the period of the Pax Romana (roughly the first two centuries A.D.), and that " $[t]$ he terror of the Roman arms added weight and dignity to the moderation of the emperors." 69

Eighteenth-century patriots similarly conjured terrible pasts for their own nations. In 1727 Roger Acherley, an advocate of Parliamentary checks on monarchical power, imagined an original assembly of Britons in which a constitution was made. Among the things agreed to at this meeting was the creation of a navy whose mission it was to "carry Terror to the Enemies Coasts, in Distant Regions.”70 In 1775

${ }^{66}$ Abbé Mably, “De l’étude de l’histoire. À Monseigneur le Prince de Parme,” in Euvres complètes, vol. $12,109$.

${ }^{67}$ Abby de Mably, Observations sur les romains (Geneva, 1751), 200-1.

${ }^{68}$ Abbé (Gabriel François) Coyer, "La noblesse commerçante," (1756) in Oeuvres de M. l'Abbe Coyer, de l'Académie Royale des Sciences \& Belles-Lettres de Nanci (London [i.e. Paris?], 1765), vol. 2, 65.

${ }^{69}$ Gibbon, Decline and Fall, vol. 1, 10.

${ }^{70}$ Roger Acherley, The Britannic Constitution: or, the Fundamental Form of Government in Britain. Demonstrating, the Original Contract Entred into by King and People, ... Wherein is Proved, that the Placing on the Throne King William III. was the Natural Fruit and Effect of the Original Constitution (London, 1727$), 55$. 
Nicolas Bricaire de La Dixmerie wrote in the guise of a "Gallic Sybil” who intoned, "The Gaul has stopped being formidable to the Nations? He used to bring war to all inhabited climes; his name alone used to spread terror among a hundred bellicose Peoples.”71

As this last example indicates, the value that eighteenth-century writers placed on the capacity to terrify is particularly clear in narratives of decline. Referring to a once-terrible individual or group dramatized the decline that had supposedly taken place in the meantime. Thus the disgruntled courtier and memorialist, the Duc de Saint-Simon, writing toward the middle of the eighteenth century but reporting events that had taken place during the reign of Louis XIV, described "the Grand Condé,” the aristocrat who had led the Fronde rebellion during the Sun King's minority, as "once the terror of that reign.” The word “autrefois,” meaning “once” but conveying the sense of “once upon a time,” emphasized the fact that this condition no longer obtained. Saint-Simon completed his description by noting that this former terror had been "trembling (tremblant) before his Ministers [of state], since his return” following the Peace of the Pyrennies in $1659 .{ }^{72}$ Similarly, but with more respect, the Dreux du Radier described Charles VIII, the fifteenth-century king who had swiftly obtained great gains for France in Italy but then lost them just as quickly: “[T]his great prince, who had been the terror of Italy and the admiration of all of Europe at the age of 17 years, died at 27 on a bad straw mattress.”73

Writers also signaled the decline of states or nations by underscoring the terror they had once exhibited. Giannone, for example, described the fall of Rome in terms of a loss of the ability to terrify. The Romans had fallen

prey to all sorts of luxury and softness. From [being] strong and magnanimous they became effeminate and weak; from [being] serious, severe and uncorrupted, [they became] full of ambition and dissolution. In this way military discipline declined and became enervated; one saw

${ }^{71}$ Nicolas Bricaire de La Dixmerie, La Sibyle gauloise, ou la France telle qu'elle fut, telle qu'elle est, \&c telle, à peu-près, qu'elle pourra être. Ouvrage traduit du celte (Londres [i.e. Paris], 1775$), 5$.

${ }^{72}$ Mémoires de Monsieur le Duc de S. Simon, ou l'observateur véridique, sur le règne de Louis XIV, \& sur les premières époques des règnes suivans (London [i.e. Paris?], 1789), vol. 1, 97.

${ }^{73}$ (Jean-François) Dreux du Radier, Tablettes historiques et anecdotes des rois de France, depuis Pharamond jusqu'à Louis xiv ... (1759; reprint: London, 1766), vol. 2, 14. 
those arms that had once carried terror and victorious banners to the ends of the earth become so vile and faint-hearted that they were no longer capable of repressing the forces of those very same nations over which they had triumphed time and time again; but to their eternal ignominy, they surrendered and let themselves be conquered shamefully, so that soon the whole empire was broken and miserably run through. ${ }^{74}$

The parallelism of the word "terror" and such obviously laudatory designations as "strong," "magnanimous" and "uncorrupted” makes it clear that Giannone valued this quality in a nation.

Regarding more recent national declines, Frederick the Great wrote to Voltaire that "the weakness of the generals, and the timidity of counsel” in Sweden as well as in France "have almost destroyed the repuation of these two nations whose very name less than fifty years ago inspired terror in Europe.”75 The days of Louis XIV and Charles XII, kings whose exploits had elicited Voltaire's plaudits, were over. Nor would this be the last time Frederick mused on Sweden's waning terror. In his history of Brandenburg, the Prussian king recalled the first decade of the eighteenth century, when the Swedes were the "terror of the North," and upon his sister Louisa Ulrike’s accession to the Swedish throne in 1751, he wrote her a poem in which he reminded her that Sweden had "once” (autrefois) been "[the] terror of Denmark, [the] scourge of Russia.”76 Evidently he hoped for a restoration of Swedish terror to help him further his geopolitical designs. The decline of Sweden was also on the mind of the marquis de Marbois, whose "Pompadour” wrote to the comte d'Argenson in 1748, “The Swedes have lost their glory by gaining their freedom,” a reference to the recent limitations placed on the monarchy by the Riksdag (Parliament). The Swedes "were the terror of the north, for as long as they were slaves to their kings: now they are free, and they do nothing." 77 Of course, this analysis represented the thinking of a tyrant, as Barbé-Marbois intended to defame Pompadour (and by extension Louis XV); but the implicit response

\footnotetext{
${ }^{74}$ Giannone, Istoria civile, vol. 1, 107.

${ }^{75}$ Frederick II, King of Prussia, to Voltaire, September 7, 1743. In Besterman, ed., Euvres complètes, vol. 92, 456. (letter D2832).

${ }^{76}$ Frederick II, Mémoires pour servir à l'histoire de Brandebourg (Berlin [i.e. London?], 1750), 182 ; and “Épitre XI. A ma soeur de Suede,” Euvres du philosophe de Sans-Souci (Potsdam, 1760), 152.

${ }^{77}$ François, marquis de Barbé-Marbois, Lettres de Madame la Marquise de Pompadour, depuis MDCCLIII jusqu'à MDCCLXII, inclusivement (London, 1774), vol. 3, 93.
} 
was that other factors had led to Sweden's decline, not that it was preferable for a nation to lose its status as "terror."

Even the Inquisition and the Jesuits, the bane of philosophes and Protestants, could be described in the eighteenth-century as a former terror if the need to diminish their prestige exceeded the need to publicize their misdeeds. Thus Antoine Jacques Roustan, a Swiss Protestant and disciple of Rousseau wrote: “This powerful and famous Order [the Jesuits] which formed the most redoubtable militia, and which played such a large part in the sufferings of our Fathers, is proscribed forever in the majority of Catholic States and humiliated even in those where they are still allowed to remain: All the other religious Orders in France are experiencing the same disgrace.” On the Inquisition, he wrote: “The fearful Tribunal of the Inquisition is feeling slip from its bloody hands this murderous sword with which it struck so many victims on the banks of the Tagus (i.e. in Lisbon).” Even the Popes were afraid of making use of the Inquisition, which was “once the terror, now the source of contempt of peoples.”78

Claims of British decline were similarly cast in terms of lost terror. An Englishman who had spent several years in Jamaica noted in 1728 that the Anglo-Jamaicans "who once were able to keep the proud Spaniards in awe, and to strike a Terror throughout America, now require our Aid, and the utmost Care and Tenderness to preserve it." ${ }^{\text {79 }}$ The parallelism between terror and awe in this passage is striking. In 1748 Raynal reported that at the beginning of Queen Anne’s reign - and before "the terror and the glory of English arms” were "brought all the way to the banks of the Danube" - the country was in a bad way. "Its armies which had always been keen, always triumphant, always invincible, were nothing more than monstrous corps without discipline, without intelligence. Its Generals whose sole name had inspired terror and admiration saw themselves the toy of their enemies and their soldiers." ${ }^{80}$ For Raynal, national decline was reversible, and terror that once affected ones enemies could return under the right

${ }^{78}$ Antoine Jacques Roustan, Réponse aux difficultez d'un théiste: ou supplément aux lettres sur l'état présent du Christianisme (London, 1771), 184.

${ }^{79}$ Some Observations on the Assiento Trade, As It Hath Been Exercised by the South-Sea Company; Proving the Damage, Which Will Accrue thereby to the British Commerce and Plantations in America, And Particularly to Jamaica (London, 1728), 33.

${ }^{80}$ Abbé Raynal, Histoire du parlement d’Angleterre (London [i.e. Paris ?], 1748), 351-2, 335-6. 
circumstances. Worried Britons were not always so certain. Thus in 1756 one correspondent wrote to The Monitor, the London newspaper edited by the Radical reformist Richard Beckford, complaining about the shortage of British soldiers willing to fight the French and their indigenous allies in America, and asking, “[A]re these soldiers, whose ancestors were a terror throughout the whole earth, so degenerate as not to be capable of carrying on a warfare with a handful of French, and undisciplined savages?”81 The racial overtones in this missive are unmistakable. The author has clearly absorbed the language of degeneration popularized by Buffon's natural history and used it to explain the challenge posed by “savages.” Equally striking, however, is the use of terror as an indicator of a nation's health.

\section{Terror, Regeneration and the French Revolution}

By the time of the French Revolution, then, the ideal of terrible rulers and nations had become a commonplace of political discourse. Among other kinds of writing, historiography helped to make this intellectual climate possible. Terrible nations of the past provided examples for emulation, though the trope of the "once terrible" highlighted the transience of this quality and the need to summon it through extraordinary efforts. Part of the "regeneration” promised by the French Revolution, I would like to suggest, was an imagined return to a lost condition of terribleness.

Discourses of terror were present from the very beginning of the French Revolution. On June 15, 1789, two days before the representatives of the Third Estate declared themselves the National Assembly, the comte de Mirabeau urged them to take that momentous step. He reminded them that while they deliberated "time has passed, the usurpations of the [first] two orders," i.e. the clergy and nobility, "have accumulated." "Now is the moment to reassure your minds," he continued, “and to inspire wariness [la

${ }^{81}$ Letter to the editor, February 28, 1756, in The Monitor: or, British freeholder (London, [1756]), vol. 1, no. 30, 276. On the editor's radicalism see Marie Peters, “The 'Monitor' on the Constitution, 1755-1765: New Light on the Ideological Origins of English Radicalism,” The English Historical Review 86 (Oct., 1971): 706-727; and Bob Harris, "The London Evening Post and Mid-Eighteenth-Century British Politics," The English Historical Review 110 (Nov., 1995): 1146. 
retenu], fear [la crainte], I almost said the terror of respect [la terreur du respect] in your adversaries by showing, from your first operations, the prudence of competency joined with the sweet firmness of reason.” ${ }^{2}$ This “almost said” suggests a reluctance to employ the term “terror," but a reluctance intended for the rhetorical effect of evoking the idea all the more strongly. Moreover, the linkage between terror and respect was explicit.

Other revolutionaries followed suit. At the end of July 1789, two weeks after the storming of the Bastille, Dominique-Joseph Garat praised the terrible effects of popular justice. He addressed his fellow lawmakers in the National Assembly, acknowledging that "the people armed itself, blood flowed,” but it was blood "of the guilty." Moreover, "These terrible examples intimidated the rest of our enemies." ${ }^{83}$ In the early days of the Revolution the concept of popular terror was widely thought compatible with support of the monarchy. Thus the conservative curé of the parish of Congis near Meaux gave a sermon titled $L a$ constitution vengée des inculpations des ennemis de la revolution, in which he advocated broad monarchical powers. As under the Old Regime, he linked terror with majesty, declaring, "If by the majesty of the throne, you understand, messieurs, an authority without limits or an arbitrary authority, an absolute power over the life, the liberty, the fortunes of citizens, this vast patrimony of abuse with which our kings played, or rather which a mob of ambitious, greedy and plundering men divided among themselves under their [the kings'] august name, I admit loudly that the new constitution destroys and annihilates this majesty of the throne." On the other hand, he continued, "if by majesty of the throne you understand, as you must, a sufficient power for executing the laws, protecting the weak against the strong, stimulating commerce, defending the patrie from the perverse designs of foreign and rival powers, commanding respect and inspiring confidence at home, imposing consideration and instilling terror

${ }^{82}$ Reimpression de l'ancien Moniteur, seule histoire authentique et inaltérée de la Révolution française depuis la réunion des Etats-Généraux.... (Paris, 1850-54), vol. 1, no. 7. (June 10-15, 1789), 71. [cf. "Onzième lettre du Comte de Mirabeau à ses commettans. Des 13, 14, 15, 17 \& 17 Juin [1789],” in Courier de Provence, 8-9].

${ }^{83}$ L'ancien Moniteur, vol. 1, no. 30 (July 30, 1789), 244. 
abroad, in a word, the power to do good and the impotence to do bad, then I maintain that the new constitution, very far from debasing the majesty of the throne, raises it infinitely. ${ }^{84}$

The invocation of terror from the right and left should not be surprising, given what we have seen of the traditions that linked this concept to legitimacy. Indeed, it was possible to invoke the primordial source of sovereign terror, i.e., God, when endorsing the Revolution. Thus the Protestant pastor Marron celebrated the completion of the Constitution in September 1791 by paraphrasing Psalm 2, "Why are the kings of the earth conspiring and plotting vain things against the Eternal and his anointed one? The Eternal will laugh at their insane plots; he will speak to them in his indignation; he will fill them with terror [les remplira de terreur]." ${ }^{85}$

One year later there would be considerably less enthusiasm about the "anointed one,” who was deposed on August 10,1792, and the butchery of the September Massacres added a new dimension to national terror. Meanwhile the foreign enemies (namely Austria and Prussia) alluded to in Marron’s psalmodic threat only grew in importance as invasion seemed to place the Revolution and its supporters in grave peril. On September 23, 1792, two days after the declaration of a Republic, Minister of the Interior Roland effused that the word "Republic" itself was "the terror of all traitors." 86 Clearly the magical thinking associated with a sovereign's name had made a smooth transition from the Old Regime through the Constitutional Monarchy and into the republican regime.

Terror became enshrined even more explicitly in the definition of the new French polity. Indeed, terribleness was a quasi-official trait of the French nation. On 27 Brumaire (November 17, 1793) Robespierre sponsored the following decree: “The National Convention declares, in the name of the French people, that the constant resolution of the French Republic is to show itself to be terrible to its

\footnotetext{
${ }^{84}$ L'ancien Moniteur, vol. 4, no. 116 (April 26, 1790), 208.

${ }^{85}$ L'ancien Moniteur, vol. 10, no. 288 (October 15, 1791), 111.

${ }^{86}$ L'ancien Moniteur, vol.14, no. 268 (September 24, 1792), 27
} 
enemies, generous to its allies, just to all peoples.”87 There is a striking parallelism between this programmatic statement and the Old Regime coronation oath that required the king to be the terror of "foreigners and plotters" while protecting widows, orphans, and "all servants of the Church." ${ }^{88}$ The new Church was the Republic. The Durkheimian “transfer of sacrality” that Mona Ozouf has seen in revolutionary festivals was effected in part by a restoration of the majesty of terror. ${ }^{89}$

When an unnamed representative of the sans-culottes addressed the Convention on September 4, 1793, calling for the punishment of the "traitorous” Girondin deputies who had been proscribed during the insurrection of May 31-June 2 and urging the lawmakers, "put terror on the agenda [placez la terreur à l'ordre du jour]," he was drawing on a lexicon that centuries of sovereigns and their supporters had used to legitimize their rule. ${ }^{90}$ The same could be said of numerous other invocations of terror "on the agenda." 91

Though intellectual history can only take us so far in understanding why terror became an imperative to revolutionaries, it can tell us a great deal about what made terror thinkable as a form of government and an attribute of legitimacy. Moreover, the historiographical examples on which I have focused in this essay help to explain the sense of urgency revolutionaries betrayed when insisting on placing terror on the agenda. Eighteenth-century historical representations cast terror as an sign of

${ }^{87}$ Rapport fait à la Convention nationale, au nom du comité de salut public, par le citoyen Robespierre, membre de ce comité, sur la situation politique de la république, le 27 brumaire, l'an $2^{e}$ de la république. In L'ancien Moniteur, vol. 18, no. 58 (November 18, 1793), 448; and vol.18, no. 60 (November 20, 1793), 463. ${ }^{88}$ Jackson, ed., Ordines, vol. 2, 478:

${ }^{89}$ Mona Ozouf, Festivals and the French Revolution, trans. Alan Sheridan (Cambridge: Harvard University Press, 1988), esp. 262-82.

${ }^{90}$ L'ancien Moniteur, vol.17, no. 250 (September 7, 1793), 526.

${ }^{91}$ L'ancien Moniteur, vol.18, no. 26 (October 17, 1793), 134; vol.18, no. 30 (October 21, 1793), 167; vol.18, no. 31 (October 22, 1793), 172; vol.18, no. 39 (October 30, 1793), 291; vol.18, no. 52 (November 12, 1793), 396; vol.18, no. 54 (November 14, 1793), 410; vol.18, no. 55 (November 15, 1793), 421; vol.18, no. 62 (November 22, 1793), 477; vol.18, no. 68 (November 28, 1793), 525; vol.18, no. 87 (December 17, 1793), 680; vol.19, no. 94 (December 24, 1793), 32; vol.19, no. 98 (December 28, 1793), 59; vol. 19, no. 103 (January 2, 1794), 107-8; vol.19, no. 106 (January 5, 1794), 127; no. 137 (February 5, 1794), 381; vol.19, no. 159 (February 27, 1794), 569 ; vol.19, no. 160 (February 28, 1794), 576; vol.19, no. 167 (March 7, 1794), 635; vol.20, no. 201 (April 10, 1794), 172; vol. 20, no. 241 (May 20, 1794), 511; vol. 20, no. 246 (May 25, 1794), 548; vol.20, no. 249 (May 28, 1794), 589. I am aware that reporters were fallible and may have embellished speeches in the legislative assemblies as well as other texts incorporated in the newspaper. But the sheer number of instances of terror speech convinces me that the concept of terror was frequently deployed, and even if the Moniteur sometimes interpolated the phrase "terror on the agenda," this only adds support to the idea that it was a recognizable, indeed cliché, expression. 
sovereign authority, but one which was susceptible to the vicissitudes (or "revolutions," to use the vocabulary of the day) of history. The only thing worse than lacking the terror to intimidate one's enemies into submission was to be a "once terrible" ruler or nation that devolved from that glorious state to a ridiculous or piteous condition of impotence. Since Herodotus historians have lived off the image of the Wheel of Fortune bringing some to power and deposing others. Eighteenth-century notions of degeneration only exacerbated the sense of vulnerability to national decline. With the Old Regime in ruins, was France still terrible? The concept of régénération suggested that past declines were reversible. The linkage between terrifying one's enemies and regenerating one’s nation is clear in a remark by citizens from Anjou and neighboring Brittany who met in Pontivy in January 1790 to form a "pact of union.” "Eager to give the patrie new proofs of a zeal that will remain for the rest of our days," they delared the formation of "an indissoluble coalition, an always-active force the imposing sight of which strikes with terror the rash enemies of our present regeneration." 92

An "always-active force” implied a permanence to terror, and indeed revolutionaries repeatedly insisted on its everlasting character. Behind this bold claim, however, lay the suspicion that revolutionary zeal would "moderate” and terrible tempers would cool. Hence the compulsive repetition of injunctions to be terrible. Danton, whose reputed moderation and tenuous commitment to terror ultimately led to his death, made a credo of the imperative, "Soyons terribles!"93 Paradoxically, this attempt to summon the forces of terror betrayed the doubt that the French were not yet, or not anymore, terrible. Hence the need to place it again and again "on the agenda."

Ronald Schechter

The College of William and Mary

${ }^{92}$ Pacte d'union des jeunes citoyens de Bretagne et d'Anjou, assemblés à Pontivy au mois de janvier 1790. In L'ancien Moniteur, vol. 3, no. 31 (January 31, 1790), 246.

${ }^{93}$ L'ancien Moniteur, vol.15, no. 71 (March 12, 1793), 682; vol.17, no. 215 (August 3, 1793), 295; vol.19, no. 95 (December 25, 1793), 37. 